Aligning Identity and Strategy: Corporate Branding at British Airways in the Late 20th Century

Author(s): John M. T. Balmer, Helen Stuart, Stephen A. Greyser

Reviewed work(s):

Source: California Management Review, Vol. 51, No. 3 (Spring 2009), pp. 6-23

Published by: University of California Press

Stable URL: http://www.jstor.org/stable/41166491

Accessed: 14/02/2012 16:54

Your use of the JSTOR archive indicates your acceptance of the Terms \& Conditions of Use, available at http://www.jstor.org/page/info/about/policies/terms.jsp

JSTOR is a not-for-profit service that helps scholars, researchers, and students discover, use, and build upon a wide range of content in a trusted digital archive. We use information technology and tools to increase productivity and facilitate new forms of scholarship. For more information about JSTOR, please contact support@jstor.org. 


\title{
Aligning Identity and Strategy: CORPORATE BRANDING AT BRITISH AIRWAYS \\ IN THE LATE 20th Century
}

\author{
John M. T. Balmer \\ Helen Stuart \\ Stephen A. Greyser
}

Acid Test: a conclusive test of success and value.

-Concise Oxford Dictionary (1999)

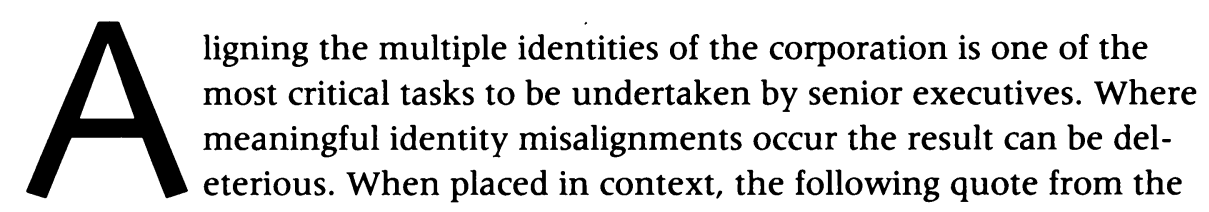
"Values" section of a company report of 1998 provides a powerful example of the damage caused by identity misalignments-in this case between corporate communications (communicated identity) and an organization's distinctive traits (actual corporate identity). It read as follows:

"We treat others as we would like to be treated ourselves. We do not tolerate abusive or disrespectful treatment. Ruthlessness, callousness and arrogance don't belong here." ${ }^{1}$

The company was Enron.

\section{The AC ID Test}

How can senior managers diagnose and resolve the identity misalignments that regularly characterize their organization? The framework outlined here seeks to address the above. ${ }^{2}$ It is based on the premise that there are six

The authors acknowledge the support and observations of faculty colleagues and students at Strathclyde University, Bradford School of Management, Brunel University, Queensland University of Technology, The Catholic University of Australia, and Harvard Business School with whom we have shared our insights from the early 1990s vis-à-vis the various identity changes effected at British Airways (see also Appendix). The authors appreciate the helpful comments of three anonymous reviewers. 
Aligning Identity and Strategy: Corporate Branding at British Ainways in the Late 20th Century

TABLE I. Balmer's AC ID Test of Corporate Brand Management

\begin{tabular}{|c|c|c|c|}
\hline Critical Concern & Identity Type & Concept & Time Frame \\
\hline What we really are & Actual & Corporate Identity & Present \\
\hline What we say we are & Communicated & $\begin{array}{l}\text { Corporate } \\
\text { Communications }\end{array}$ & Past/Present \\
\hline What we are seen to be & Conceived & Corporate Image & Past/Present \\
\hline What the brand stands for & Covenanted & Corporate Brand & Past/Present \\
\hline What we ought to be & Ideal & Corporate Strategy & Future \\
\hline What we wish to be & Desired & CEOVision & Future \\
\hline
\end{tabular}

Note: See Appendix A for background information on the AC ID Test and further background on the BA study

critical identity types/questions that senior executives of the modern corporation need to ensure are broadly calibrated with each other. Each of the aforementioned is characterized by a distinct identity type, linked to a corporate-level concept/issue of fundamental importance.

The six facets of the framework form the acronym $\mathrm{AC}^{3} \mathrm{ID}$ Test (actual, communicated, conceived, covenanted, ideal, and desired). The modus vivendi of the framework is that senior executives should ensure that there is dynamic congruence rather than perfect alignment among the six identity types that inform this framework. Of course, there will never be absolute alignment among the various identity types: indeed, it would be hazardous if this were to be the case since in our view this would characterize a myopic and moribund institution. The changing dynamic of the external environment (as captured by the ideal identity) means that change is an indispensable "life giving" characteristic of organizations of whatever type. Our characterization of corporate identity ("Actual Identity") reflects the current understanding of corporate identity in terms of an organization's defining characteristics rather than reflecting the traditional concern with systems of visual identification. ${ }^{3}$ Table 1 outlines the principal characteristics of Balmer's $\mathrm{AC}^{3} \mathrm{ID}$ framework, which in this version has been adapted to include the important dimension of the corporate brand.

\section{The Changing Face of British Airways}

In this article, we examine six identity-related eras that have characterized the recent history of British Airways (BA). ${ }^{4}$ In selecting BA as the primary vehicle for elaborating the identity framework discussed here, we were able to draw on the close associations that we, both individually and collectively, have with the airline and its senior management since the early 1990s. In addition, the recent history of British Airways is a powerful and interesting narrative of corporate survival, recovery, and success that has few parallels. It is an account of how a struggling, loss-making, and moribund state-owned airline overcame 
considerable inertia and metamorphosed into a customer-focused, profitable, and publicly traded corporation. It is a narrative of how identity-based views of the corporation were, intuitively, at the forefront of the strategic thinking of senior figures within the airline. The managers who piloted British Airways from the late 1970s to the turn of the millennium were Lord King and Lord Marshall, and we draw on their comments to us over the last two decades about the momentous changes they effected during these years. Under their charge, they implemented a series of identity changes that in our view were audacious, dramatic, and, for the most part, highly successful.

In chronicling BA's transformation over the last three decades we employ the $\mathrm{AC}^{3} \mathrm{ID}$ Test framework outlined above. However, our analysis also shows the inherent difficulties of correctly discerning strategic misalignments as characterized by one dramatic failure to align the airline's identities in the late 1990s, namely, BA's "World Images" graphic design and related communications initiatives.

\section{The Early Years}

BA's provenance is a truly remarkable one. Its roots are to be found in the halcyon days of the British Empire when, in 1924, four small British airlines were merged to become what was then known as Imperial Airways. ${ }^{5}$ Established at the behest of the British Government,

John M.T. Balmer is a Professor of Corporate Marketing, Brunel University, London and quondam Professor of Corporate Identity/Brand Management, Bradford University; he is founder/chairman of the International Corporate Identity Group.

$<$ John.Balmer@brunel.ac.uk>

Helen Stuart is a Senior Lecturer in Marketing, School of Business and Informatics, Australian Catholic University, Brisbane. <Helen.Stuart@acu.edu.au>

Stephen A. Greyser is the Richard P. Chapman Professor (Marketing/Communications) Emeritus, Harvard Business School and co-author (with John Balmer) of Revealing the Corporation: Perspectives on Identity, Image, Reputation, Corporate Branding and Corporate-Level Marketing. <sgreyser@hbs.edu> the airline provided important means of transport and a critical communications network not only for well-to-do passengers, but also, critically, for those involved in affairs of state that were dispatched to all parts of the imperial realm. To burnish Britain's prestige and what was seen as Imperial Airways' preeminence, the British Government gave financial support to the airline; this mirrored the approach taken by Continental European governments, which also supported their countries' fledgling airlines. As part of this policy, Imperial Airways was granted a national monopoly. Imperial Airways had, de facto, become not only an instrument of Pax Britannica, but also a marque of Britishness in national and international contexts.

In 1935, concerns about Britain's aviation interests on the European Continent and in South America by the British Government led to the birth of a sister airline to Imperial Airways, British Airways $(B A)$. In its formative years it was led by the legendary Lord Reith, who had previously served as the first director general of the British Broadcasting Corporation (BBC) and the architect of what became internationally known as public sector broadcasting. The brand name of British Airways was to disappear temporarily in 1939 with the nation- 
FIGURE I. British Airways Identity Misalignments (circa mid-1970s through early 2000s)

\begin{tabular}{|c|c|c|}
\hline Era & Time Frame & Identity Imperative \\
\hline "Appalling" Era & Pre-1980s & Aligning the Actual with the Ideal identity \\
\hline "Adjusting" Era & Early 1980s & Aligning the Actual with the Desired identity \\
\hline "Appealing" Era & Mid-1980s & Aligning the Communicated with the Ideal identity \\
\hline "Adoring" Era & $\begin{array}{l}\text { Late 1980s/ } \\
\text { Early 1990s }\end{array}$ & Aligning the Communicated with the Covenanted identity \\
\hline "Astonishing" Era & Late 1990s & $\begin{array}{l}\text { Aligning the Communicated with the Desired Identity (but BA failed } \\
\text { to take cognizance of the Actual and Covenanted identities) }\end{array}$ \\
\hline "Affirming" Era & Early 2000s & Aligning the Communicated with the Covenanted identity \\
\hline
\end{tabular}

alization of the British airline sector, but arose, phoenix-like, in 1974 when the state-controlled airline sector was restructured with the establishment of a single national carrier.

It is at this juncture in the airline's history that we begin our examination of $\mathrm{BA}$ by making reference to the $\mathrm{AC}^{3} \mathrm{ID}$ Test. The six eras of identity change described below are outlined in Figure 1 and cover the distinct periods from the late 1970 s to the early years of this century. The fact that so many identity misalignments occurred during such a relatively short period of time clearly suggests that examining the corporation via the lenses of identity is not merely desirable, but is indeed a strategic necessity.

\section{British Airways "Appalling" Era: Pre-1980s (Aligning Actual and Ideal Identities)}

Our narrative begins in earnest in 1974 when British Overseas Airways Corporation (BOAC) and British European Airways (BEA) merged in order to form a single, nationalized airline carrier: British Airways. However, the circumstances surrounding BA's birth were far from propitious and did not augur well for the fledgling brand. Specifically, as a state concern, the airline suffered from government inertia, rising debt, lack of strategic focus, ineffective management, and, significantly, was characterized by a product orientation rather than customer orientation. For instance, many pilots were former Royal Air Force officers who, although they had impeccable credentials as top-notch pilots, appeared to view BA as a type of flying club for the upper crust. Certainly, they appeared to have a myopic mindset when it came to passengers: their usual previous cargo had, more often than not, been bombs. Internally, there were tensions; BOAC's employees, who worked on intercontinental routes, adopted a superior attitude to their colleagues of BEA who staffed the less-glamorous routes in Great Britain and on the Continent. Back in 1994, remarking on this era, Sir John King (later ennobled as Lord King of Wartnaby) told us that the prevailing attitude of these pilots was that flights "were something of a jolly" and 
that if the public wished to join them for a spin, well, "they were welcome." ${ }^{16} \mathrm{BA}^{\prime} \mathrm{s}$ monopoly on national routes and its indifferent levels of service led to BA earning the sobriquet "Bloody Awful" among the media and travelling public. Moreover, the carrier's labor relations were generally considered to be frightful and there was a general consensus that BA was over manned. ${ }^{7}$ This explains why we have characterized this era as "appalling."

There were, however, some aspects of the airline's situation that were both unique as well as positive. Among BA's identity assets were the flight-deck personnel who were reputed to perform to exacting standards of safety, Britain's imperial past that had resulted in the establishment of an extensive global route network, and BA's privileged access to London's Heathrow Airport-arguably the world's most profitable airport for carriers. As Lord Marshall told us:

"There is no doubt that the state-owned British Airways, which emerged from the amalgamation of BEA and BOAC, was technically proficient with high operating and maintenance standards. The problem was that, for many economic and political reasons, the airline had become over-manned and driven by the needs of its own production processes, not by those of the marketplace. This introversion caused it to lose sight of the customer."

Looking at the above through an identity lens, we conclude that the principal identity problem confronting the airline during this period was the lack of alignment between the ideal identity (what we ought to be) with the actual identity (what we really are). A myopic, product-oriented mindset, demoralized staff, a lack of funding, and weak leadership characterized the actual identity. Yet, what is palpably obvious is that BA required a strategy where the corporate identity was not only substantively customer-focused, safe, and profitable (ideal identity), but also one that capitalized on its assets.

\section{British Airways "Adjusting" Era: Early 1980s (Aligning Actual and Desired Identities)}

By 1981, BA had a new chairman, Sir John King. British Prime Minister Margaret Thatcher had appointed King to undertake the task of turning the airline from a loss-making, state-owned concern to a profitable company in the private sector. This was part of a radical agenda by the British Government ("Thatcherism") where the frontiers of the British State were to be rolled-back and, for state-owned entities such as BA, they were to be subject to the strictures of market forces. ${ }^{8}$ As he described it to us, two concerns were uppermost in the mind of Sir John: first, to place the airline on a firm financial footing and, second, to improve staff self-esteem.

Financially, BA was under clear strictures from the British Government that had moved away from the dirigisme policies that had characterized British industry during the 1970s. However, the turn-around was to be done without further resources from the government. Prime Minister Thatcher constantly reminded BA's chairman, as he told us back in 1994, of the government's mandate with the words, "Remember John, there is no money." He was also charged by the Prime Minister to prepare the airline for privatization, so King appointed a 
new board of directors consisting of individuals who had the requisite commercial and marketing skills. The appointment of Colin Marshall as BA's CEO was to prove to be the most propitious of King's appointments.

King was confronted with a dire financial situation: BA carried an overdraft of almost $€$ lbn. As he told us:

"The first, and most important, change I made at BA was to establish the business on a stable financial basis. Without cash there could be no question of improving the company's image or changing the company's identity. Without cash a company simply ceases to exist."

Drastic measures were called for, and routes, capacity, and non-core activities were pruned.

Although many airline staff were made redundant, King was determined to bolster employee morale, realizing that this is a prerequisite for a servicebased organization. Reflecting on staff morale during this period, Lord Marshall commented:

"Employees, especially those in direct customer contact, had become disillusioned and demotivated. None of them, I believe, went to work wanting to do a bad job but the system worked against them. Turning round the people was the prerequisite to turning round the business."

A decade later, Lord King recalled for us how and why BA had initiated a brief focused communications program directed primarily at employees. In our terms, this initiative was aimed at capturing King's vision (desired identity) for the airline and communicating change from the actual identity of that period. A highly visible component of the program took place in conjunction with the Queen's televised annual message on Christmas afternoon. At peak familyviewing time, a multi-minute advertorial-style BA commercial message emphasized the positive aspects of the airline, implying a turn-around with brighter prospects.

Although employees (and their families) were the principal target audience, the use of television for a "feel good about BA" message broadened the audience substantially to other stakeholders, including customers, vendors, influential individuals, and members of the general public (who were the airline's ultimate owners as a state-owned entity).

Clearly this was an expensive step and to many an audacious approach. It became a topic of considerable discussion and debate. Although seen as a heroic gesture by some, it also had its detractors, who were amazed at the profligacy of the gesture. Lord King told us that his critics had completely missed the point, since to him such efforts were not so much a luxury as a commercial necessity:

"Many thought, "What an expensive piece of marketing'! Well, they missed the point! At the time BA's workforce had been cut by one third, the quality of service was a joke for many customers, and employees for years had been reading how much the company was losing. I wanted an advertisement that would make my staff feel proud." 
In the earlier "appalling" period, we saw how the airline urgently needed to transform its actual identity (moribund and product-led) to that of an ideal identity (customer-focused and commercially viable concern).

The principal identity problem confronting the airline during this period was the lack of alignment between the desired identity (what we wish to be) with the actual identity (what we really are). The engine of change was the vision (desired identity) of Lord King, who imbued his indelible mark on the organization not only through his appointment of a new board of directors, but, in addition, by the importance accorded to staff (as evinced by the communications initiative described above).

\section{British Airways "Appealing" Era: Mid-1980s (Aligning Communicated and Ideal Identities)}

As the airline moved inextricably towards privatization, King wanted the negative associations of the airline's former identity to be consigned to history. There was a need to communicate this to customers, employees, and would-be investors in the privatized corporation. Although King was an accomplished communicator, he realized that BA required the services of a consummate marketer to oversee the next stage of the carrier's evolution and Colin Marshall was identified as the best person to fill this role and was duly appointed as CEO (with King holding the position of Chairman of BA). Marshall's credentials were impeccable in that he not only had held senior management positions at Avis (in its "We try harder" period), Hunt-Wesson foods, and the British retailer Sears, but, importantly, had first-hand customer experience as a purser on the Orient Shipping Line that operated between Great Britain and the Antipodes. His role at BA was one that was to attract considerable attention on the global stage. ${ }^{9}$

At this juncture, it is important to note that the process of identity alignment (especially the radical transformation of the actual identity so that it calibrated with the ideal identity) can take many years to effect. As Colin Marshall noted, the task of turning around the airline was akin to an archaeological dig in that once the dust and debris of ages had been cleared, the jewels could be uncovered and the brightest of them would be the very professional and highly skilled BA employees. However, they operated in an environment that was antithetical to a market-led and customer focused organization. ${ }^{10}$ In response, Marshall initiated and personally drove an ambitious and exhaustive training program entitled "Putting People First," the primary accent of which was one of superior customer service. He also led from the front and was highly visible, mingling with crew and passengers alike. Surveying this period, Lord Marshall outlined to us the enormity of the task confronting BA:

"What effectively we had to do was throw away the past-the aircraft fleets and their on-board service, the airport facilities and passenger-handling systems, the reservations procedure and sales process-in fact, the entire inherited corporate identity. All we had left, mentally, were the customers and it was their choices and preferences-identified by consultation, market research, and personal dialogues-that formed the base for re-building." 
With his considerable experience as a marketer, Colin Marshall intuitively realized that the corporate communications (communicated identity) also needed to mirror BA's strategy (ideal identity). Under Marshall's leadership, such a transformation was executed quickly and with a style appropriate to the challenge. For example, a new system of visual identification was commissioned from Landor (the renowned San Francisco-based graphic design consultancy); this resulted in the adoption of an assured, arresting, and contemporary house style that incorporated a recognizably British design vernacular: heraldry. This seemed to complement in graphic design terms what Marshall's staff training programs aimed to achieve: a traditional Britishness equated with calmness, efficiency, and politeness. In a similar mode, the de facto adoption of a corporate musical theme (the Flower Duet from Delibes' opera Lakme) was accorded a high profile, and it was used with some flair in BA's advertisements, in-flight communications, and call centers. In another bold move, Marshall retained Saatchi \& Saatchi, a rising and innovative firm in the advertising agency world led by the legendary Saatchi brothers. The agency's advertisements for BA were considered among the most creative and celebrated of this period.

Having begun the task of changing the actual identity, a key activity of this period (and leading up to privatization) was for the communicated identity (what we say we are) to reflect the ideal identity (what we ought to be). This was being articulated via various communications channels, including a new visual identity, a creative advertising campaign, and the adoption of a theme tune, among others.

\section{British Airways "Adoring" Era: Late 1980s, Early 1990s (Aligning Communicated and Covenanted Identities)}

In 1987, British Airways was privatized and became perhaps the most celebrated privatization program of the Thatcher government, with visibility on the global stage. However the metamorphosis of British Airways was far from complete. Both Marshall and King realized that the airline's fortunes would, to a considerable degree, be dependent on BA attaining as well as communicating brand values to global audiences. To us, these corporate brand values needed to connote high quality and élan, and at the same time signal accessibility to a broad set of audiences. This would enable the airline to establish a strong bond with customers as well as bolster the emotional bond with employees. In this context, a corporate brand is akin to a covenant, in that at its apogee it represents an emotional and thereby powerful compact between the corporation and its stakeholders: the brand name is linked to certain associations and expectations.

Although corporate branding is closely related to an organization's identity, it is not, we believe, an identical construct. In effect, it relates to the summation of the organization's identity in terms of an espoused set of identifiable values, and in turn becomes shorthand for recognizing and evaluating a company's activities. For staff it provides a standard for service delivery. For customers and other key stakeholder groups it represents the organization's covenant with 
them reflected in performance and service. Taking a broader historical context, airlines such as Pan American World Airways and KLM-Royal Dutch Airlines have long appreciated the efficacy of an integrated corporate identity and branding strategy. ${ }^{11}$

There was much from BA's heritage to distill from its actual identity in building its brand (covenanted identity) including its enviable international network, its privileged position at Heathrow Airport, its legacy of innovation (it was one of two carriers then offering supersonic flights on Concorde), its safety record, its dramatically enhanced customer service, and positive associations garnered from a certain type of traditional Britishness. Furthermore, in 1992 the magazine Air Transport World awarded BA the title of Airline of the Year: one in fifteen passengers taking an international flight anywhere flew with BA. ${ }^{12}$

It was from this that BA developed a brand positioning platform based on the strap line "The World's favourite airline," uttered by the internationally recognized English actor Robert Morley. Speaking to us about this period, Lord Marshall remarked:

“By this time, we were engaged in a strategy to build a global airline for a global marketplace. In addition to our own growing network, we had secured important international commercial partnerships and investments across the world. Overseas markets now accounted for no less than $60 \%$ of our total business."

Lord Marshall went on to elaborate his view of the critical importance of BA's corporate branding activities and how this materially contributed to the airline's success during this period:

"Introducing the concept of branding was crucial. Not only was this a groundbreaking innovation for British Airways, it was also a completely new-probably revolutionary-idea for the airline industry in general. The aim was to create a product, or set of products, which offered a distinctive style and delivered consistency in terms of facility, service, and quality throughout. Market differentiation meant that we could command a premium for our services and hold up margins in a cutthroat business. Rather than discount and devaluate our products, we competed by giving customers significantly more style and value. Our employees responded enthusiastically because they wanted to be identified with high quality, not mediocrity."

By this time, people across the entire BA organization had come to embrace the customer-focused philosophy espoused by senior management. Lord Marshall saw the then-current professional and highly skilled staff (both those retained from the past and those subsequently recruited) as the foundation of a successful customer-centered brand. In this regard, Marshall later referred to himself as "driven by evangelistic determination to strive for customer service excellence." The principles of the aforementioned "Putting People First" training program (initiated in the "Appealing" era) had permeated all levels of staff. Indeed, Lord Marshall very recently related with pride that administrative staff not among the groups scheduled for training had sought to be involved; their view was that "we support customers indirectly by supporting BA frontline staff." Moreover, recognition of the program and British Airways' success led 
to requests for BA to advise other organizations about analogous initiatives. In essence, the program had achieved organization-wide "buy-in" internally and considerable praise externally-both key components of BA's successful corporate brand building in this era.

A key task of this period was for the airline's communications (communicated identity) to reflect BA's corporate branding credentials in global contexts (covenanted identity); thus corporate advertising was to have a particular prominence. During this period the inventiveness and panache of the Saatchi communications program reached new heights: for instance in one commercial 1,000 colorfully dressed extras formed a human visage that winked and smiled. A truly human element of change related to staff identity. Lord Marshall recalls:

"One of the small, but very important, changes we made was to insist that all staff wear a badge giving their names and job titles. No longer were our people anonymous "airline officials," but identified professional individuals, instantly accountable to their customers and to each other."

In a very real sense, BA had turned rhetoric into reality and had begun to align its corporate communications activities (communicated identity) to capture key features of BA's corporate brand promise (covenanted identity).

\section{British Airways "Astonishing" Era: Late 1990s (Corporate Mis-Diagnosis of Identities-A Failure to Take Cognizance of the Actual and Covenanted Identities)}

In 1996, Robert Ayling became the new CEO of British Airways with Colin Marshall taking the role of Chairman. Research commissioned by BA revealed that 60 percent of British Airways customers were not British, leading the CEO to conclude that this necessitated BA asserting its global credentials and giving less prominence to its British heritage. (We have not been able to learn whether BA's research had ascertained why existing passengers travelled with BA or the degree to which passengers found the airline's British characteristics to be attractive or not-nor do we know the impact of any such research on reaching a decision.) What appears to be the case is that the resultant change appeared to reflect the sincerely held vision of the CEO and the board (desired identity) and was not the result of thorough research and strategic analysis (ideal identity).

The above change of direction meant that BA's livery (the appearance of BA's fleet and its graphics), which had a decidedly British character, and had not been altered since 1984, sat uncomfortably with the airline's new global positioning. In a very radical, and certainly audacious, change of visual identity Newell and Sorrell (a London-based graphic design consultancy) introduced a design architecture consisting of not one but fifty national symbols drawn from all corners of the world: a single design (of the fifty) adorned the tailfin of every plane. The aim was to reflect the global customer base of BA. At the time, Robert Ayling asserted that the change was much deeper than the paint and was:

"[the] physical manifestation of a fundamental review of our mission, values, and our corporate goals." 13 
The task of repainting an airline fleet with so many different designs was mammoth and complex; the process of change was code-named "Utopia." In retrospect, the choice of code name was to prove inauspicious.

By downplaying its national credentials, BA had unwittingly alienated key members of its corporate brand community and generated a good deal of opprobrium from the public, media, British Members of Parliament, as well as disbelief from BA staff members. One commentator was incredulous that BA had adopted images from countries whose airlines would only be used as a last resort when confronted faced by an extreme emergency. ${ }^{14}$ Margaret Thatcher communicated her dissent by draping a handkerchief over a tail fin of a model British Airways plane at the Conservative Party conference in 1997. She was not alone in her disquiet; British travelers, the other 40 percent of passengers, particularly disliked the non-British tailfins and the change attracted much media attention. ${ }^{15}$

In the U.S., some of those travelling to the UK were flabbergasted that African and Asian symbols, rather than British iconography, adorned BA's fleet. Moreover, BA's key constituency felt alienated-British citizens who comprised $40 \%$ of its customer base, and critically the many British business travelers who paid premium rates for their business class seats. In short, many in Great Britain loathed the new house style: it was seen as a national affront in that it downplayed Britishness and severely undermined British confidence. Capitalizing on BA's misguided predicament, Sir Richard Branson (head of BA's rival airline Virgin Atlantic and founder of the eponymous Virgin brand) asserted that Virgin was now "Britain's flag carrier" and that his airline's livery would accord prominence to the British flag. ${ }^{16}$

Lord Marshall, in reflecting on this most troublesome of periods in the recent annals of BA observed to us:

"As it turned out, the airline had gone too far, too fast for its key stakeholderscustomers, shareholders, employees-and the British public. The change was too drastic and in the view of many weakened the strength of our brand. There was also the perception that the proud heritage of British Airways was being swept under a carpet of modernization."

In reflecting on the above, it is clear that the policies pursued by BA's executives were sincerely held and were executed with the courage and energy that had characterized BA's corporate psyche since the 1980s. Although BA was successful in aligning the communicated identity (what we say we are) with the desired identity (what we wish to be) this was undertaken without recourse to the airline's actual identity (what we really are) and its covenanted/corporate brand identity (what we promise) and the ideal identity (what we ought to be.) As such, the initiative proved to be ill-judged. In addition, it would appear that corporate identity here (unlike earlier changes of identity) was narrowly conceived in terms of emphasizing graphic design to reflect management vision.

Another caveat needs to be introduced here, because certain "national" brands are characterized by a strong proprietary and emotional bond. As such, some corporate brands have a role in defining the self and, moreover, the nation, 
as with the case of BA. For this reason the corporate community can be national rather than institutional in scope.

\section{British Airways "Affirming" Era: Early 2000s (Identity Misalignments: Communicated and Covenanted Identities)}

The furor caused by the change led to what can be described only as a dramatic volte face on behalf of BA. The global symbolism that adorned BA's fleet was gradually replaced by a single British-inspired visual image: the (British) flag as flown by Admiral Nelson at the Battle of Trafalgar. In both instances (1805 and the late 1990s), an overseas "threat" had been eradicated and the Union Flag of Britain endured, triumphant. On March 10, 2000, BA's troubled chief executive Robert Ayling stepped down and was replaced by an Australian with an impressive track record in the airline industry, Rod Eddington. ${ }^{17}$

Eddington initiated a new strategy whereby British Airlines was to be positioned as a "premium airline," a carrier that accorded primary importance to its long-haul routes and to its business passengers. ${ }^{18}$ As with other full-service airlines, BA had to take account of the emergence of no-frills airlines such as Easy Jet and RyanAir (in Europe), Jet Blue and Southwest (in the U.S.) and Air Asia, Jet Airways, Tiger Air, and Virgin Blue (in Asia and Australasia). Eddington realized that BA could no longer afford to be, or claim to be, the "World's Favourite Airline" by being all things to all people.

Confiding to us about this difficult period Lord Marshall noted:

"With the appointment of a new Chief Executive Officer (bringing in a new style and fresh strategies was the perfect catalyst for change) the decision was therefore taken to scrap the 'world images' program and give every aircraft in the fleet the British Union Flag livery originally chosen for Concorde."

He went on to tell us that:

"There is no doubt that the brand has been significantly re-strengthened. Customers, employees, and casual observers have rallied behind a new, focused image which strongly reaffirms the airline's British heritage and its commitment to quality that does not detract from its global status."

The previous dilemma, whether BA should be perceived as British or not, seems a distant memory in the present competitive climate in which British Airways is affirming its identity.

\section{Conclusions: The Strategic Role of Corporate Identity}

In bringing our narrative of British Airways to a close we leave the reader with the recent reflections provided by Lord Marshall upon the strategic role played by corporate identity in the metamorphosis of British Airways over the past four decades:

"It is clear that corporate identity and brand image are completely inter-linked and, in many cases, are one and the same. It is equally apparent that corporate and brand identity are living entities. Once launched and accepted, they no longer 
belong to the management of an organization, but to all its stakeholders-customers, shareholders, employees, business partners, and suppliers. The job of management is to take custody of corporate identity and brand image, to protect them and to strengthen them in the face of new business opportunity and fresh business challenge. In these days of greater expectations from business (corporate governance, environmental care), established brands have more responsibilities than pure commerce and corporate identities will have to shoulder them."

In our view, adopting an identity-based view of the corporation as encapsulated in the $\mathrm{AC}^{3} \mathrm{ID}$ Test affords a critically important means by which senior executives can understand and manage their organizations strategically. As our narrative reveals, calibrating an organization's various identities-so that in their totality they form a meaningful whole-requires constant vigilance on the part of senior executives and their advisers. The framework encompasses a variety of disciplinary sources and time frames and accommodates internal corporate as well as external perspectives.

We have seen how over a considerable period of time, senior management of British Airways, by adopting an identity-based view of the firm, ${ }^{19}$ effected strategic change within the airline, albeit with one notable failure. We concur with Lord Marshall that the melding of corporate identity and corporate brand management constitutes a strategic imperative for contemporary organizations. Whereas custodianship of an organization's identities resides with senior executives, the ultimate owners are of course customers, employees, and other key stakeholder groups.

\section{Lessons for Senior Management}

Three insights emerge from our examination of British Airways through an identity lens:

- Adopting an identity-based view of the corporation affords a powerful means through which we can comprehend key facets of contemporary organizations that need to be part of the strategic deliberations of senior executives.

- An audit of the multiple identities of the corporation should be undertaken at regular intervals and the $\mathrm{AC}^{3} \mathrm{ID}$ Test provides an effective means of undertaking this task.

- The strategic imperative of achieving dynamic and meaningful alignment among the multiple identities of the organization is such that senior managers should ensure that it is part of their strategic deliberations (as appeared to be the case with Lords King and Marshall).

Finally, as the British Airways case history reveals, major identity misalignments were a frequent occurrence over the period studied, illustrating the point that identities can be dynamic and are evolutionary. Moreover, they are of considerable strategic importance. 
APPENDIXA

Background Information on BA Case Study and the AC ID Test

\section{British Airways Case Study}

This draws on Professor Balmer's research on British Airways, which began in the early 1990s and which draws on his discussions and other materials made available to him by the late Lord King of Wartnaby and Lord Marshall of Knightsbridge - both held positions as CEO and Chairman of British Airways. Both have given keynote presentations at Professor Balmer's ICIG (International Corporate Identity Group) symposia in 1994 (Lord King), 2001 (Lord Marshall), and 2007 (Lord Marshall). Also, these symposia provided a forum where identity consultancies discussed their work for BA including Landor in 1994 and Newell and Sorrell in 1999. It also marshals Dr. Helen Stuart's long-time scrutiny of identity developments at BA, which have informed her elective courses on the area at undergraduate and postgraduate levels and conference presentations. Professor Greyser's intellectual interests and his participation in both the ACID Test's evolution and the British Airways symposium sessions are also incorporated.

\section{The AC ID Test}

Dating back to the late 1990 s and developed and refined over many years by Professor Balmer, the $\mathrm{AC}^{3} \mathrm{ID}$ test framework aims to meet the needs of senior managers and their advisors by providing a diagnostic tool for identifying identity misalignments. The test grew out of a substantive stream of intellectual work undertaken within the UK and USA, including data collected from major corporate identity/brand consultancies and an extensive literature review of corporate identity including its formation and management. It was found that identity misalignment was a common occurrence among contemporary organizations and took different forms. The ACID Test was devised to detect such identity and brand misalignments and greatly extends identity interface theory and accommodates the various disciplinary roots that underpin the multiple identities of the corporation. The six identity types that characterize the revised framework (which accommodates the increasingly important dimension of the corporate brand) forms the acronym $\mathrm{AC}^{3} \mathrm{ID}$ :

\section{A ACTUAL IDENTITY}

The distinctive attributes of the organization, including business activities, purposes, corporate style and ethos, markets covered.

\section{COMMUNICATED IDENTITY}

The messages emitted from the organization. This encompasses outward-directed communication such as visual identification (logos), corporate advertising, and corporate public relations. 


\section{CONCEIVED IDENTITY}

The images and reputations of the organization held by customers and other stakeholder groups.

\section{COVENANTED IDENTITY}

The underlying promise that is associated with the corporate name and/or logo. However, owing to the power and strength of association towards a corporate brand on the part of customers, employees, and others (which sometimes has a religious-like fervor), the term covenant appears to be appropriate.

\section{IDEAL IDENTITY}

The optimum strategic (future-oriented) positioning of the organization in a given time frame. This is established after organizational competencies, assets, the competition, and changes in the political, economic, ethical, social, and technological environment have been scrutinized.

\section{DESIRED IDENTITY}

The sought-after future positioning of the organization that lives in the hearts and minds of corporate leaders: it is their vision for the organization's identity in a given time frame. (This identity type is cognitive/aspirational in character whereas the Ideal identity is strategic in nature.)

\section{APPENDIX B Acknowledgements}

Both individually and collectively, Professor Balmer wishes to thank Lord Marshall of Knightsbridge and (the late) Lord King of Wartnaby for their assistance in our individual and collaborative work relating to British Airways, including keynote addresses delivered at symposia organized by him and for ongoing contact since then. The ACID Test had its origins in a major study Balmer led in the mid-1990s undertaken at Strathclyde University, Glasgow. Professor Balmer wishes to acknowledge and thank Dr. Guillaume Soenen who assisted him in the formative stage of the model's development. He also thanks Professor Stephen A. Greyser for his long-time collaboration and friendship and his role as a special advisor for the Strathclyde, Bradford, and Brunel symposia and the Trans-Atlantic Identity Study. He also is thankful to the global branding consultancy Enterprise IG for its support of the early field research that informed the initial ACID Test.

This longitudinal study of BA has been used as a case study from the early 1990s onwards as part of the MBA degree at Strathclyde University and then (from 1999) as part of the MBA (full time), MBA (Executive BBC degree), and MBA (Emirates Airlines) programs offered by Professor Balmer while at Bradford School of Management. It has also been used by Dr. Helen Stuart as part of her postgraduate and undergraduate courses both at QUT and at the Catholic University of Australia. In 2007, Professors Balmer and Greyser along with Lord 
Marshall of Knightsbridge delivered a keynote presentation on this case history to postgraduates attending the MSc in Corporate Brand Management at Brunel University, London, and to visiting identity and corporate branding experts from practice. We have shared our insights on BA with overseas colleagues at major international forums and through working papers and we are grateful for their observations. Details are as follows: J.M.T. Balmer and H. Stuart, "Anatomy of an Identity Crisis: The Case of British Airways," conference paper, The 4th International Conference on Corporate Reputation, Identity and Competitiveness, Copenhagen Business School, May 18-20, 2000; J.M.T. Balmer and H. Stuart, "British Airways and Balmer's AC ${ }^{3}$ ID Test of Corporate Brand Management." in J. Wiley and P. Thirkell, eds., Marketing Accountabilities and Responsibilities: Proceedings of the Australia and New Zealand Marketing Academy Conference, Victoria University, Wellington, New Zealand, November 29-December 1, 2004; J.M.T. Balmer and $\mathrm{H}$. Stuart, “British Airways and Balmer's AC ${ }^{3}$ ID Test of Corporate Brand Management," Bradford School of Management Working Paper 04/26, July, 2004; J.M.T. Balmer and H. Stuart, "Balmer's AC ${ }^{3}$ ID Test and Corporate Social Responsibility of Corporate Identity and British Airways," The 9th International Conference on Corporate Reputation, Identity and Competitiveness, Reputation Institute Conference, Madrid, May 19-22, 2005; J.M.T. Balmer, S. Greyser, and Lord Marshall, "Identity and Strategy: The Evolution of British Airways 1980early 2000s," 10th ICIG Symposium, Brunel University, London, November 30, 2007.

\section{Notes}

1. S. McNulty, "Tour of Booty," Financial Times Magazine, June 3-4, 2006, pp. 22-25.

2. This article draws on Professor Balmer's latest version of the ACID Test Framework (which encompasses the added dimension of the covenanted identity). See J.M.T. Balmer and E.R. Gray, "Corporate Brands: What Are They? What of Them?" European Journal of Marketing, 37/7-8 (2003): 972-997. Earlier versions of the framework were reported in J.M.T. Balmer and S.A. Greyser, "Managing the Multiple Identities of the Corporation," California Management Review, 44/3 (Spring 2002): 72-86; J.M.T. Balmer, "From the Pentagon: A New Identity Framework," Corporate Reputation Review, 4/1 (Spring 2001): 11-22; J.M.T. Balmer and G.B. Soenen, "The Acid Test of Corporate Identity Management ${ }^{\mathrm{TM}}$," Journal of Marketing Management, 5/1-3 (January-April 1999): 69-92.

3. The following is a representative list of relevant identity-based literature that underpins this study.

For an overview of corporate identity/customer identification, see: John M.T. Balmer, "Corporate Identity and the Advent of Corporate Marketing," Journal of Marketing Management, 14/8 (November 1998): 963-996; C.B. Bhattacharya and S. Sen, "Consumer-Company Identification: A Framework for Understanding Consumers' Relationships with Companies," Journal of Marketing, 67/2 (April 2003): 76-88; T.C. Melewar and E. Karaosmanoglu, “Seven Dimensions of Corporate Identity: A Categorization from the Practitioners' Perspectives," European Journal of Marketing, 40/7-8 (2006): 846-869.

For an overview of corporate identity management/formation, see: C. Simões, S. Dibb, and P.R. Fisk, "Managing Corporate Identity: An Internal Perspective," Journal of the Academy of Marketing Science, 33/2 (Spring 2005): 153-168; H. Stuart, "Towards a Definitive Model of the Corporate Identity Management Process," Corporate Communications, 4/4 (1999): 200-207; G. Bick, M.C. Jacobson, and R. Abratt, "The Corporate Identity Management Process Revisited," Journal of Marketing Management, 19/7-8 (September 2003): 835-855.

For an overview of organizational behaviorists' perspectives on what they term organizational identity, see: Stuart Albert and David A. Whetten, "Organizational Identity," Research in Organizational Behavior, 7 (1985): 263-295; D.M. Gioia, M. Schultz and K.G. Corley, “Organizational Identity, Image and Adaptive Instability," Academy of Management Review, 25/1 (January 
2000): 989-1018; M.J. Hatch and M. Schultz, eds., Organizational Identity: A Reader (Oxford: Oxford University Press, 2004).

For the literature explicitly covering the strategic nature of identity, see: H. Bouchikhi and J.R. Kimberly, The Soul of the Corporation: How to Manage the Identity of Your Company (Upper Saddle River, NJ: Wharton School Publishing, 2008); H. Bouchikhi and J.R. Kimberly, "Escaping the Identity Trap," MIT Sloan Management Review, 44/3 (Spring 2003): 20-26; H-W. He and J.M.T. Balmer, "Perceived Corporate Identity/Strategy Dissonance: Triggers and Managerial Responses," Journal of General Management, 33/1 (Autumn 2007): 71-92.

For a comparison of multi-disciplinary perspectives of identity, see: J.M.T. Balmer, "Corporate Marketing: Apocalypse, Advent and Epiphany," Management Decision, $47 / 4$ (2009) 544-572; J.M.T. Balmer, "Identity Based Views of the Corporation: Insights from Corporate Identity, Organisational Identity, Social Identity, Visual Identity and Corporate Image," European Journal of Marketing, 42/9-10 (2008): 879-906; J.P. Cornelissen, S.A. Haslam, and J.M.T. Balmer, "Social Identity, Organizational Identity and Corporate Identity: Towards an Understanding of Processes, Patternings and Products," British Journal of Management, 18 (March 2007): 1-16; M.J. Hatch and M. Schultz, "Relations Between Organizational Culture, Identity and Image," European Journal of Marketing, 31/5-6 (1997): 356-365; H-W. He and J.M.T. Balmer "Identity Studies: Multiple Perspectives and Implications for Corporate-Level Marketing," European Journal of Marketing, 41/7-8 (2007): 765-785; M. Schultz, M.J. Hatch, and M.H. Larsen, eds., The Expressive Organization (Oxford: Oxford University Press, 2000).

For an overview of corporate identity vis-à-vis other corporate-level constructs, see: $\mathbf{R}$. Abratt, "A New Approach to the Corporate Image Management Process," Journal of Marketing Management, 5/1 (Summer 1989): 63-76; John M.T. Balmer, "Corporate Identity, Corporate Branding and Corporate Marketing-Seeing Through the Fog," European Journal of Marketing, 35/3-4 (2001): 248-291; John M.T. Balmer and S.A. Greyser, "Corporate Marketing: Integrating Corporate Identity, Corporate Branding, Corporate Communications, Corporate Image and Corporate Reputation," European Journal of Marketing, 40/7-8 (2006): 730-741; John M.T. Balmer and Stephen A. Greyser, Revealing the Corporation: Perspectives on Identity, Image, Reputation, Corporate Branding and Corporate-Level Marketing (London: Routledge, 2003); John M.T. Balmer and Stephen A. Greyser, "Managing the Multiple Identities of the Corporation," California Management Review, 44/3 (Spring 2002): 72-86; T.J. Brown, P.A. Dacin, M.G. Pratt, and D.A. Whetten, "Identity, Intended Image, Construed Image and Reputation," Journal of the Academy of Marketing Science, 34/2 (Spring 2006): 99-106; M. Cardador and M. Pratt, "Identification Management and Its Bases: Bridging Management and Marketing Perspectives through a Focus on Affiliation Dimensions," Journal of the Academy of Marketing Science, 34/2 (Spring 2006): 174-184; T.C. Melewar, ed., Facets of Corporate Identity, Communication and Reputation (London: Routledge, 2008); Cees B.M. van Riel and Charles J. Fombrun, Essentials of Corporate Communication (London: Routledge, 2007).

For an overview of corporate brand identity, see: J.M.T. Balmer, "Scrutinising the British Monarchy: The Corporate Brand that was Shaken, Stirred and Survived," Management Decision, 47/4 (2009): 639-675; S.A. Greyser, "Corporate Brand Reputation and Brand Crisis Management," Management Decision, $47 / 4$ (2009): 590-602; J.M.T. Balmer and I. Thomson, "The Shared Management and Ownership of Corporate Brands: The Case of Hilton," Journal of General Management, 34/4 (2009): 15-37; B. Merrilees and D. Miller, "Principles of Corporate Rebranding," European Journal of Marketing, 42/5-6 (2008): 537-552; A. Mukherjee and J.M.T. Balmer, "New Frontiers and Perspectives in Corporate Brand Management: In Search of a Theory," International Studies of Management and Organizations, 37/4 (2008): 3-19; M. Urde., S.A. Greyser, and J.M.T. Balmer, "Corporate Brands with a Heritage," Journal of Brand Management, 15/1 (2007): 4-19; K.L. Keller and K. Richey, "The Importance of Corporate Brand Personality Traits to a Successful 21 st Century Business," The Journal of Brand Management, 14/1 (2006): 74-81; D.A. Aaker, "Leveraging the Corporate Brand," California Management Review, 46/3 (Spring 2004): 6-26; P.A. Argenti and D. Druckenmiller, "Reputation and the Corporate Brand," Corporate Reputation Review, 6/4 (2004): 368-374; S. Knox and D. Bickerton, "The Six Conventions of Corporate Branding," European Journal of Marketing, 37/7-8 (2003): 998-1016; M. Schultz and M.J. Hatch, (2003) "The Cycles of Corporate Branding," California Management Review, 46/1 (Fall 2003): 6-26; J.M.T. Balmer and E.R. Gray, “Corporate Brands: What are they? What of them?" European Journal of Marketing, 37/7-8 (2003): 972-997; J.M.T. Balmer, "Corporate Branding and Connoisseurship," Journal of General Management, $21 / 1$ (1995): 24-47. 
4. The significance of the repositioning(s) of British Airways' identity over the last two decades is such that it has been a significant leit motif within the marketing, management, and graphic design literatures. See Jeremy Aynsley, Pioneers of Modern Graphic Design (London: Mitchell Beazley, 2001); John M.T. Balmer and E.R. Gray, "Corporate Identity and Corporate Communications: Creating a Competitive Advantage," Corporate Communications, 4/4 (1999): 171-176; John M.T. Balmer "The Three Virtues and Seven Deadly Sins of Corporate Brand Management," Journal of General Management, 27/1 (Autumn 2001): 1-17; Peter Dormer, Design Since 1945 (London: Thames and Hudson, 1993); Stephen King, "Brand Building in the 1990s," Journal of Marketing Management, $7 / 1$ (January 1991): 3-13; M.J. Hatch and M. Schultz, "Bringing the Corporation into Corporate Branding," European Journal of Marketing, 37/7-8 (2003): 1041-1064.

5. D.G. Jeremy, A Business History of Britain, 1900-1990s (Oxford: Oxford University Press, 1999), p. 31.

6. Lord King of Wartnaby, speech given at the First International Corporate Identity Group's (ICIG) Symposium on Corporate Identity, University of Strathclyde, Glasgow, June 1994.

7. R. Green and I. Vogelsang, "British Airways: A Turn-Around Anticipating Privatization," in M. Bishop, J. Kay, and C. Mayer, eds., Privatization and Economic Performance (Oxford: Oxford University Press, 1994).

8. Lord Skidelsky, "The Growth of a World Economy," in Sir Michael Howard and William Roger Louis, eds., The Oxford History of the Twentieth Century (Oxford: Oxford University Press, 1998), pp. 60-61; Adair Turner, Just Capital: The Liberal Economy (London: Pan Books, 2002), pp. 202-203; The Encyclopedia of Britain (London: Helicon Publishing, 1999), p. 884.

9. S.E. Prokesch, “Competing on Customer Service: An Interview with British Airways' Sir Colin Marshall," Harvard Business Review, $73 / 6$ (November/December 1995): 101-112; Sir Colin Marshall, "British Airways: From Apprentice Ship's Purser to CEO: A Journey in Search of the Customer," in William Dauphinais and Colin Price, eds., Straight From the CEO (London: Nicholas Brealey, 1998), pp. 135-140.

10. Sir Colin Marshall, ibid.

11. Jeremy Aynsley, Pioneers of Modern Graphic Design (London: Mitchell Beazley, 2001), p. 132; Peter Dormer, Design Since 1945 (London: Thames and Hudson, 1993), p. 108.

12. "Airline of the Year: British Airways," Air Transport World, 30/2 (1993): 33-34.

13. Information from British Airways Website See <www.british-airways.com>.

14. .I. Stelzer, "The Sorry Tale of British Airways' Weakened Brand," The Times (of London), March 25,1999, p. 31.

15. J. Curtis, "Global BA Queries British Roots," Marketing, March 13, 1997, p. 1; R.W. Moorman, "The Emperor's New Clothes," Air Transport World, 9 (1997): 93-95; "BA's Profits Slump as Love Affair Cools," The Guardian (Newspaper), November 10, 1998, p. 5; "Would BA Lose Out by Staying British?' Marketing (Magazine), March 13, 1997, p. 5; J.D. Morrocco, “British Airways Dons New Global Image," Aviation Week $\theta$ Space Technology, 146/25 (1997): 81.

16. B. Rosler, "BA and Virgin Prepare for the Battle of the Flags," Marketing (Magazine), June 10, 1999, p. 5.

17. J. Ashworth, "Writing Was on the Wall for Ayling," The Times (of London), March 11, 2000, p. 8; M. Harrison, "Heathrow, We Have a Problem: Can Bob Ayling Put the Wheels Back on British Airways?" The Independent (Newspaper), May 26, 1999, p. 6; H. Skapinker, "The Last Ride of Bob Ayling," Financial Times, March 12, 2000, p. 14.

18. D. Rogers, "BA to Tempt Back Business People with 5.3 Million (Pounds Sterling) Push," Marketing (Magazine), January 10, 2002, p. 1.

19. The concept of identity-based views of the organization is outlined in John M.T. Balmer, "Identity Based Views of the Corporation: Insights from Corporate Identity, Organizational Identity, Social Identity, Visual Identity and Corporate Image," European Journal of Marketing, 42/9-10 (2008): 879-906. 